Kindrat I. $P$.

\title{
DETERMINATION OF USNIC ACID EFFECT ON IRON METABOLISM IN RAT LIVER
}

\author{
Ivano-Frankivsk National Medical University, Ukraine
}

Irakindrat0603@gmail.com

A wide range of environmental toxic substances causes adverse effects on organism and may represent a serious threat to human health. Exposure to xenobiotics may cause a broad range of metabolic disturbances, including iron homeostasis. Iron is both an essential trace element to the body and potentially toxic substance in excess. Perturbations in iron metabolism relate to the growing of various pathological states, including liver toxicity development and progression. Liver is the most important organ for a metabolic process and detoxification of harmful substances, along with iron storage and homeostasis.

Usnic acid is a well-studied secondary metabolite isolated from lichens, which is extensively studied the broad variety of biological features. It is reported that usnic acid is effective for a range of pharmacological purposes such as antiviral, antimicrobial, antiproliferative, antiprotozoal, antitumor and anti-inflammatory. (+)-Usnic acid has been marketed as an ingredient of dietary supplements to promote weight loss. However, some studies reported that usnic acid has been associated with clinical cases of liver toxicity and contact allergy depending on the doses, thus its potential use as a drug is limited.

However, there are limited data on the impact of usnic acid on iron homeostasis in the liver. The purpose of the present study was to investigate the possible effect of usnic acid on iron metabolism in rat liver.

Material and methods. Male Fischer 344 rats ( 6 weeks of age) were housed in sterilized cages in a temperature-controlled room $\left(24^{\circ} \mathrm{C}\right)$ with a $12 \mathrm{~h}$ light/ dark cycle, and given ad libitum access to water and $\mathrm{NIH}-41$ irradiated pelleted diet. Gene expression in the liver of rats was analyzed by quantitative reverse transcription polymerase chain reaction techniques. Analysis of hepatic iron content was measured by inductively coupled plasma mass spectrometry.

Results and discussion. The results showed that treatment of Fischer 344 (F344) rats with 60 mg usnic $\mathrm{acid} / \mathrm{kg}$ bw/day for 6 weeks increased the expression of iron metabolism-related genes, Ftl and Fth, while the level of Tfrc mRNA was decreased in rat liver. Additionally, exposure of rats to usnic acid resulted in decrease of hepatic cellular iron content.
Conclusion. The obtained results demonstrated that the exposure of rats to a low dose of usnic acid resulted in changes in the expression of iron metabolism related genes.

Keywords: usnic acid, iron metabolism, liver, toxicity.

Research relation to the programs, plans, and department themes. The work is a fragment of research work «Development of methods of diagnosis, treatment and prevention of dental diseases in the population living in environmentally unfavorable conditions", the number of state registration is 011 U003681. The study was partially conducted at the National Center for Toxicological Research, USA.

Introduction. Usnic acid $\left(\mathrm{C}_{18} \mathrm{H}_{16} \mathrm{O}_{7}, U A\right)$ is a prominent secondary metabolite, that has been used for various purposes worldwide, found in lichens especially abundant in the Alectoria, Cladonia, Evernia, Lecanora, Ramalina and Usnea genera [1, 2]. UA found in two enantiomeric forms: (-) L-usnic acid and (+) D-usnic acid, indicating an R or S projection of the methyl group at position 9b. Both enantiomers possess a broad spectrum of different biological activities [3].

The cumulative data show that UA have been used as traditional medicines for antimicrobial, antiprotozoal, antimycotic, antiviral, antiproliferative, antioxidation, analgesic, antipyretic, anti-inflammatory, wound-healing purposes, chelation of heavy metals, antitumor effects in different cell types and UV light protection [1-3]. Moreover, UA is used as an ingredient of powder, toothpaste, sunscreens, deodorants, cream, hair shampoos, and mouthwash [1]. During the past decade, UA has been also used for weight loss as a component of some dietary supplements because of its ability to increase fat metabolism and to raise basal metabolic rate [3, 4]. However, it has been reported that dietary supplements containing UA are associated with acute liver failure and toxicity $[5,6]$.

The liver is the predominant organ involved in biotransformation of endogenous compounds, xenobiotics [7] and it plays a significant role in iron homeostasis [8]. Iron is an essential element involved in a 
broad range of important physiological and molecular processes [9]. Among the known proteins that regulate iron homeostasis, expression of Tfrc, Ftl, Fpn1 and Fth - iron metabolism-related genes, are the main ones involved in iron homeostasis changes. In particular, Tfrc gene is known to encode the transferrin receptor 1 , which is responsible for iron import from transferrin into cells by endocytosis [15]. Changes in expression of these proteins induced by xenobiotics could lead to an impaired iron metabolism system and, as a consequence, to the development of chronic liver diseases and to the formation of cancer in this organ [10]. Therefore, hepatic iron homeostasis plays an important role in protecting liver from injuries induced by hepatotoxicants.

However, despite evidences reporting the effects of UA on liver toxicity, to these days there is still no data regarding the association of UA on iron metabolism.

In the light of these considerations, the purpose of this study was to investigate the effect of hepatic toxicant UA on the metabolism of iron in rat liver.

\section{Materials and methods}

Animals, experimental design, and treatments

Male Fischer 344 rats (6 weeks of age) were housed in sterilized cages in a temperature-controlled room $\left(24^{\circ} \mathrm{C}\right)$ with a $12 \mathrm{~h}$ light/dark cycle, and given ad libitum access to water and $\mathrm{NIH}-41$ irradiated pelleted diet. After one week of acclimation, the rats were allocated randomly to control and experimental groups. Rats in the experimental group ( $n=6$ per treatment) were treated by gavage 5 days per week with doses of $60 \mathrm{mg} \mathrm{UA} / \mathrm{kg} \mathrm{bw/day} \mathrm{dissolved} \mathrm{in} \mathrm{DMSO.} \mathrm{UA} \mathrm{was}$ purchased from Sigma-Aldrich (CAS No. 7562-61-0). Animals in the control groups $(n=6)$ were gavaged with DMSO only. Body weights were recorded weekly for adjustment of drug dosages. Rats were euthanized by exsanguination following deep isoflurane anesthesia after 6 weeks of treatments. The livers were excised and snap-frozen immediately in liquid nitrogen and stored at $-80{ }^{\circ} \mathrm{C}$ for subsequent analyses. All experimental procedures were carried out in accordance with the International Rules for the Use of Experimental Animals.

RNA extraction and quantitative reverse transcription-PCR

Total RNA was extracted from liver using miRNeasy Mini kits (Qiagen, Valencia, CA) according to the manufacturer's instructions. Total RNA $(2 \mu \mathrm{g})$ was reverse transcribed using random primers and High Capacity cDNA Reverse Transcription kits (Life Technologies, Grand Island, NY) according to the manufacturer's protocol. cDNA was analyzed in a 96-well plate PCR assay format using a Quant Studio ${ }^{\mathrm{TM}}$ 7 Flex Real-Time PCR System (Life Technologies,
Carlsbad, CA). Each plate contained experimental genes and a housekeeping gene $\beta$-actin; (Actb). All primers for the gene expression analysis were obtained from Life Technologies: transferrin ( $T f)$, transferrin receptor (Tfrc), ferritin light chain (Ft), ferritin heavy chain 1 (Fth), Solute carrier family 40 member 1 (Slc40a1 (Fpn1)). The relative level of each transcript was determined using the $2^{-\Delta \Delta C t}$ method [11].

Analysis of hepatic iron content by inductively coupled plasma mass spectrometry

Inductively coupled plasma mass spectrometry was used to measure the total hepatic iron content in the livers of control and UA-treated rats. Briefly, microwave dissolution of the liver samples was performed with $4.0 \mathrm{ml}$ of concentrated $\mathrm{HNO}_{3}$ using $100 \mathrm{mg}$ of tissue, followed by quantitative transfer and dilution using $2 \% \mathrm{HNO}_{3}$. Tissue microwave dissolution was accomplished by the application of up to $1600 \mathrm{~W}$ power, $200{ }^{\circ} \mathrm{C}$ for $35 \mathrm{~min}$, utilizing a MicrowaveAccelerated Reaction System Model MARS-X (CEM Corporation, Matthews, NC). The iron content was determined with an Agilent 8800 Inductively Coupled Plasma mass spectrometer, utilizing the ${ }^{56} \mathrm{Fe}$ isotope. ${ }^{45} \mathrm{Sc}$, at $100 \mathrm{ng} / \mathrm{ml}$, was used as an internal standard. Helium collision cell gas was used to eliminate argon oxide $\left({ }^{40} \mathrm{Ar}^{16} \mathrm{O}^{+}\right)$poly-atomic interferences.

\section{Statistical analyses}

Statistical analyses were performed using SigmaPlot 13.0 software (Systat Software, Inc, San Jose, CA). Results are presented as mean \pm S.D. Data were analyzed by an $t$-test and one-way analysis of variance (ANOVA), with pair-wise comparisons being made by the Student-Newman-Keuls method. Values of $\mathrm{P} \leq 0.05$ were considered significant.

\section{Results}

Effect of usnic acid on the expression of iron metabolism-related genes in rat liver.

In order to investigate the major mechanisms of impaired iron metabolism during hepatotoxicity, mRNA levels of Tfrc, Tf, Ftl, Fth, and Fpn1 in rat liver that received $60 \mathrm{mg}$ usnic acid/kg bw/day were determined. Fig. 1A shows that the expression of Tfrc decreased by $30 \%$ in liver of rats treated with UA compared with the control. In contrast, the expression level of Ftl and Fth was increased by $16 \%$ and $10 \%$, respectively, in the rats of the study group.

There were no changes in the level of $T f$ and Fpn1 in the livers of F344 rats treated with UA. In addition to alterations in the expression of iron-related genes, treatment of rats with $60 \mathrm{mg}$ usnic acid $/ \mathrm{kg} \mathrm{bw/}$ day resulted in the reduction by $22 \%$ in the hepatic iron content (Fig. 1B).

Discussion. Several studies show toxic impact of UA on liver function both in vitro and in vivo [12, 13]. It is well-known that the abnormalities in hepatic iron 
A

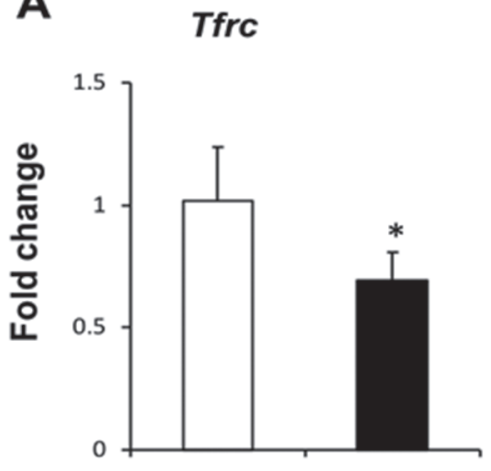

Fth

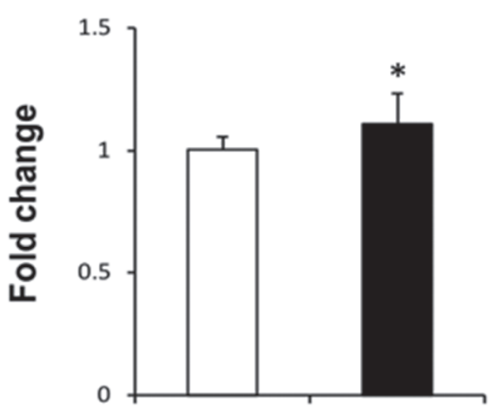

Tf

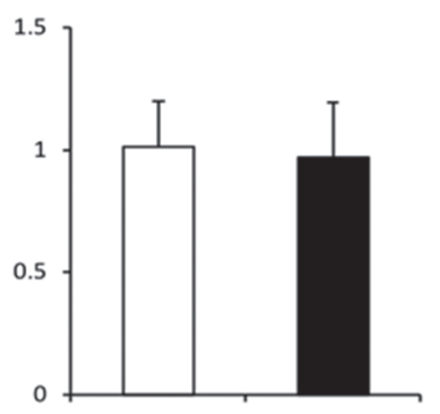

Fpn1

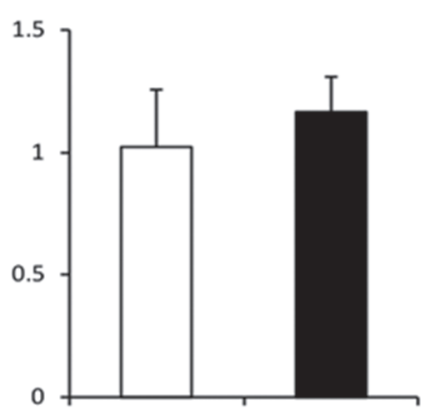

Ftl

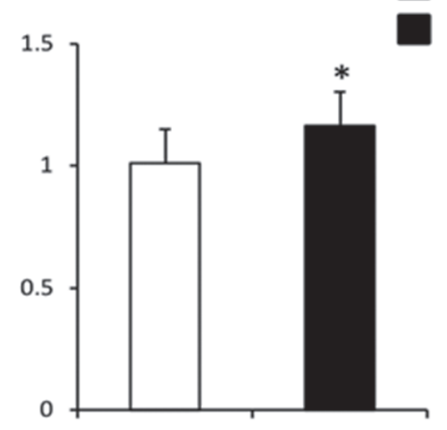

B

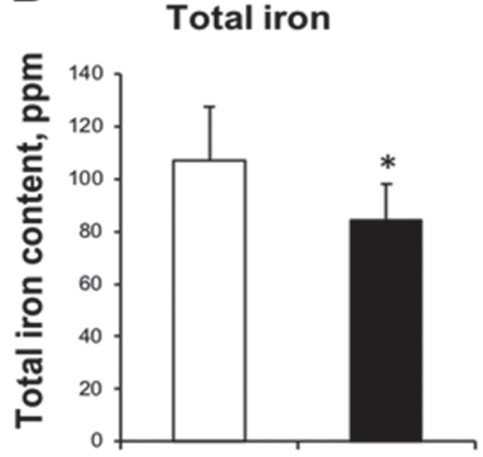

Fig. 1. Effect of usnic acid on the expression of iron metabolism-related genes Tfrc, Tf, Ftl, Fth, Fpn1(A) and on intracellular iron levels (B) in the livers of F344 rats treated with usnic acid

Note: ${ }^{*} \mathrm{P}<0.05$.

homeostasis may exacerbate liver injury induced by hepatotoxicants [14]. The results of present study demonstrate that administration of UA led to changes in the expression of iron exchange genes in rat liver, especially an up-regulation of $\mathrm{Ftl}$, Fth genes and a down-regulation of Tfrc.

As mentioned in the introduction, Tfrc gene is known to encode the transferrin receptor 1 , which is responsible for iron import from transferrin into cells by endocytosis [15]. For instance, our findings of the decrease in Tfrc in the livers of UA-treated rats correspond to the report by Shpyleva et al. [16] that showed a reduction in Tfrc expression in neoplastically transformed TRL1215 cells, exposed to sodium arsenite.

Ferritin is known to be a major protein that stores excess iron [17], whose expression level was increased in our study. Our previous study of methapyrilene-induced hepatocarcinogenesis demonstrated extensive alterations of $\mathrm{Ftl}$ in the livers of F344 rats
[18]. In contrast, the level of hepatic iron content was decreased in rats treated with UA. Similar results were demonstrated by Bloomer et al. [19], that a high-fat diet that produced histologic features of nonalcoholic steatohepatitis in mice was accompanied by increased markers of inflammation and oxidative stress and decreased hepatic iron concentrations. Other study has reported that usnic acid had $\mathrm{Fe}^{3+}$ reducing and $\mathrm{Fe}^{2+}$ chelating effect [20].

Conclusion. Among the known proteins that regulate iron homeostasis, expression of Tfrc, Ftl and Fth iron metabolism-related genes, have undergone the greatest changes in our study. Thus, the results of this work indicated changes in iron metabolism, specifically, iron reduction due to the action of UA in rat liver.

Prospects of further researches. Further studies are needed to unravel the molecular mechanisms that cause changes in iron homeostasis in liver, as well as to clarify the role of iron metabolism changes in the hepatotoxic effects of usnic acid.

\section{References}

1. Guzow-Krzemińska B, Guzow K, Herman-Antosiewicz A. Usnic Acid Derivatives as Cytotoxic Agents Against Cancer Cells and the Mechanisms of Their Activity. Curr Pharmacol Rep. 2019; 5: 429-39.

2. Francolini I, Piozzi A, Donelli G. Usnic Acid: Potential Role in Management of Wound Infections. Adv Exp Med Biol. 2019; 1214: 31-41. 
3. Guo L, Shi Q, Fang JL, Mei N, Ali AA, Lewis SM, et al. Review of usnic acid and Usnea barbata toxicity. J Environ Sci Health C Environ Carcinog Ecotoxicol Rev. 2008; 26(4): 317-38.

4. Singh N, Nambiar D, Kale RK, Singh RP. Usnic acid inhibits growth and induces cell cycle arrest and apoptosis in human lung carcinoma A549 cells. Nutr Cancer. 2013; 65(Suppl 1): 36-43.

5. Yellapu RK, Mittal V, Grewal P, Fiel M, Schiano T. Acute liver failure caused by 'fat burners' and dietary supplements: a case report and literature review. Can J Gastroenterol. 2011; 25(3): 157-60.

6. Sanchez W, Maple JT, Burgart LJ, Kamath PS. Severe hepatotoxicity associated with use of a dietary supplement containing usnic acid. Mayo Clin Proc. 2006; 81(4): 541-4.

7. Jetter A, Kullak-Ublick GA. Drugs and hepatic transporters: A review. Pharmacol Res. 2020; 154: 104234.

8. Chia-Yu W, Babitt JL. Liver iron sensing and body iron homeostasis. Blood. 2019; 133(1): 18-29.

9. Rishi G, Subramaniam VN. The liver in regulation of iron homeostasis. Am J Physiol Gastrointest Liver Physiol. 2017; 313(3): G157-G165.

10. Recalcati S, Correnti M, Gammella E, Raggi C, Invernizzi P, Cairo G. Iron Metabolism in Liver Cancer Stem Cells. Front Oncol. 2019; 9: 149.

11. Schmittgen TD, Livak KJ. Analyzing real-time PCR data by the comparative C(T) method. Nat Protoc. 2008; $3: 1101-8$.

12. Araújo AAS, de Melo MGD, Rabelo TK, Nunes PS, Santos SL, Serafini MR, et al. Review of the biological properties and toxicity of usnic acid. Natural Product Research. 2015; 29(23): 2167-80.

13. Galanty A, Paśko P, Podolak I. Enantioselective activity of usnic acid: a comprehensive review and future perspectives. Phytochem Rev. 2019; 18: 527-48.

14. Ackerman Z, Pappo O, Link G, Glazer M, Grozovski M. Liver toxicity of thioacetamide is increased by hepatocellular iron overload. Biol Trace Elem Res. 2015; 163: 169-76.

15. Prá D, Franke SI, Henriques JA, Fenech M. Iron and genome stability: an update. Mutat Res. 2012; 733(1-2): 92-9.

16. Shpyleva SI, Muskhelishvili L, Tryndyak VP, Koturbash I, Tokar EJ, Waalkes MP, et al. Chronic administration of 2acetylaminofluorene alters the cellular iron metabolism in rat liver. Toxicol Sci. 2011; 123: 433-40.

17. Recalcati S, Gammella E, Buratti P, Cairo G. Molecular regulation of cellular iron balance. IUBMB Life. 2017; 69: 389-98.

18. Kindrat I, Dreval K, Shpyleva S, Tryndyak V, de Conti A, Mudalige TK, et al. Effect of methapyrilene hydrochloride on hepatic intracellular iron metabolism in vivo and in vitro. Toxicol Lett. 2017; 281: 65-73.

19. Bloomer SA, Olivier AK, Bergmann OM, Mathahs MM, Broadhurst KA, Hicsasmaz H, et al. Strain- and timedependent alterations in hepatic iron metabolism in a murine model of nonalcoholic steatohepatitis. Cell Biochem Funct. 2016; 34: 628-39.

20. Cetin Cakmak K, Gülçin İ. Anticholinergic and antioxidant activities of usnic acid-an activity-structure insight. Toxicol Rep. 2019; 6: 1273-80.

Удк 616.36+546.72+616-092.9

\section{ВИЗНАЧЕННЯ ВПЛИВУ УСНІНОВОЇ КИСЛОТИ НА ОБМІН ЗАЛІЗА У ПЕЧІНЦІ ЩУРІВ}

\section{Кіндрат I. П.}

Резюме. Зростаюче використання ксенобіотиків різноманітної природи викликає всесвітню занепокоєність щодо їх токсичного впливу на здоров'я людини. Ксенобіотики можуть викликати широкий спектр метаболічних порушень, включаючи гомеостаз заліза. Залізо є як важливим мікроелементом для всіх живих організмів, так і потенційно токсичною речовиною при надмірному надходженні. Порушення метаболізму заліза пов'язане зі зростанням різних патологічних станів, включаючи гепатотоксичність. Печінка - один з найважливіших органів детоксикації шкідливих речовин, який виконує метаболічну функцію і являється центральним регулятором гомеостазу заліза в організмі людини. Уснінова кислота - вторинний метаболіт, виділений з лишайників, який широко використовувався як інгредієнт харчових добавок для схуднення. Деякі дослідження повідомляють, що уснінова кислота пов'язана з клінічними випадками токсичності печінки. Проте, на сьогодні відсутня переконлива інформація щодо впливу уснінової кислоти на гомеостаз заліза в печінці.

3 огляду на це, метою цього дослідження було дослідити можливий вплив УК на метаболізм заліза в печінці щурів лінії F344.

Рівень експресії генів у печінці щурів визначали методом виділення загальної РНК, зворотньої транскрипції та кількісної полімеразної ланцюгової реакції. Аналіз вмісту заліза в печінці вимірювали за допомогою мас-спектрометрії з індуктивно-зв'язаною плазмою.

Результати показали, що уснінова кислота викликала у щурів зміни в експресії генів, які кодують білки обміну заліза, особливо зростання Ftl, Fth та зниження Tfrc. Ці зміни супроводжувалися зниженням вмісту загального заліза у гепатоцитах. Водночас, уснінова кислота у дозі 60 мг/кг маси тіла тварини не викликала змін в рівні експресії Tf і Fpn1. 
Отже, дані результати досліджень демонструють, що уснінова кислота у низьких дозах викликала зміни в експресії генів, пов'язаних з обміном заліза в печінці щурів.

Ключові слова: уснінова кислота, обмін заліза, печінка, токсичність.

Удк 616.36+546.72+616-092.9

ОПРЕДЕЛЕНИЕ ВЛИЯНИЯ УСНИНОВОЙ КИСЛОТЫ

НА ОБМЕН ЖЕЛЕЗА В ПЕЧЕНИ КРЫС

Киндрат И. П.

Резюме. Растущее использование ксенобиотиков различной природы вызывает всемирную озабоченность их токсическим воздействием на здоровье человека. Ксенобиотики вызывают широкий спектр метаболических нарушений, включая гомеостаз железа. Железо является как важным микроэлементом для всех живых организмов, так и потенциально токсичным веществом при избыточном поступлении. Нарушение метаболизма железа связано с развитием различных патологических состояний, включая гепатотоксичность. Печень -важнейший орган детоксикации вредных веществ, выполняет метаболическую функцию и является центральным регулятором гомеостаза железа в организме человека. Усниновая кислота - вторичный метаболит, выделенный из лишайников, который широко использовался как ингредиент пищевых добавок для похудения. Некоторые исследования сообщают, что усниновая кислота связана с клиническими случаями токсичности печени. Однако, на сегодняшний день отсутствует убедительная информация о влиянии усниновой кислоты на гомеостаз железа в печени.

Учитывая это, целью данного исследования было изучить возможное влияние усниновой кислоты на метаболизм железа в печени крыс линии F344.

Уровень экспрессии генов в печени крыс определяли методом выделения общей РНК, обратной транскрипции и количественной полимеразной цепной реакции. Анализ содержания железа в печени измеряли с помощью масс-спектрометрии с индуктивно-связанной плазмой.

Результаты показали, что усниновая кислота вызвала изменения в экспрессии генов, кодирующих белки обмена железа, особенно рост Ftl, Fth и снижение Tfrc. Эти изменения сопровождались снижением содержания общего железа в гепатоцитах. В то же время усниновая кислота в дозе 60 мг / кг массы тела животного не вызвала изменений в уровне экспрессии Tf и Fpn1.

Таким образом, данные результаты исследований показывают, что усниновая кислота в низких дозах вызвала изменения в экспрессии генов, связанных с обменом железа в печени крыс.

Ключевые слова: усниновая кислота, обмен железа, печень, токсичность.

The authors of this study confirm that the research and publication of the results were not associated with any conflicts regarding commercial or financial relations, relations with organizations and/or individuals who may have been related to the study, and interrelations of coauthors of the article.

Стаття надійшла 09.04.2020 p.

Рекомендована до друку на засіданні редакційної колегії після рецензування 